\title{
Selection of Target Mussel Tissue for Application of Cellular Energy Allocation as a Physiological Biomarker in Native Mussels Mytilus galloprovincialis (Lamarck, 1819)
}

Author(s) :Marijana Erk, Dušica Ivanković and Željka Strižak

Source: Journal of Shellfish Research, 31(1):61-68. 2012.

Published By: National Shellfisheries Association

DOI: http://dx.doi.org/10.2983/035.031.0108

URL: http://www.bioone.org/doi/full/10.2983/035.031.0108

BioOne (www.bioone.org) is a nonprofit, online aggregation of core research in the biological, ecological, and environmental sciences. BioOne provides a sustainable online platform for over 170 journals and books published by nonprofit societies, associations, museums, institutions, and presses.

Your use of this PDF, the BioOne Web site, and all posted and associated content indicates your acceptance of BioOne's Terms of Use, available at www.bioone.org/page/terms_of_use.

Usage of BioOne content is strictly limited to personal, educational, and non-commercial use. Commercial inquiries or rights and permissions requests should be directed to the individual publisher as copyright holder. 


\title{
SELECTION OF TARGET MUSSEL TISSUE FOR APPLICATION OF CELLULAR ENERGY ALLOCATION AS A PHYSIOLOGICAL BIOMARKER IN NATIVE MUSSELS MYTILUS GALLOPROVINCIALIS (LAMARCK, 1819)
}

\author{
MARIJANA ERK,* DUŠICA IVANKOVIĆ AND ŽELJKA STRIŽAK \\ Ruđer Bošković Institute, Division for Marine and Environmental Research, Bijenička c. 54, PO Box 180, \\ HR-10002 Zagreb, Croatia
}

\begin{abstract}
Three selected mussel tissues (digestive gland, mantle, and gills) were studied to determine which was the most suitable for the potential use of the cellular energy allocation (CEA) methodology in indigenous mussels Mytilus galloprovincialis. In addition, the applicability of CEA in the assessment of natural stress caused by salinity fluctuations in stratified estuary was tested in selected tissues. It was important to identify the mussel gender to reliably assess the changes in organism energy budget. CEA value was calculated as a ratio between available energy $\left(E_{a}\right)$ and energy consumption $\left(E_{c}\right)$. Mantle tissue was under the strongest influence of the differences in protein and lipid content between male and female mussels, and therefore reflected physiological changes in the organism itself, rather than those caused by natural environmental stress. CEA in gills had lower values than in mantle and digestive gland, and was similar at two selected sampling sites, so the changes in CEA caused by natural stress could not be detected in the gill tissue. Greater $E_{c}$ in mussels from the estuarine site than from the coastal site was detected only in the digestive gland tissue, and can probably be attributed to the energetically costly maintenance of osmotic balance. Last, using digestive gland tissue in CEA analysis demonstrated a clear difference between coastal and estuarine sampling sites, providing the measure of the natural stress posed by variations in salinity.
\end{abstract}

KEY WORDS: cellular energy allocation, mussel Mytilus galloprovincialis, digestive gland tissue, mantle tissue, gill tissue

\section{INTRODUCTION}

The cellular energy allocation (CEA) methodology has been developed (De Coen \& Janssen 1997) as a biochemical alternative to the physiological scope for growth (Widdows \& Johnson 1988). It is based on the metabolic cost hypothesis, which suggests that toxic stress induces metabolic changes in an organism, which might lead to a depletion of its energy reserves, resulting in adverse effects on growth and reproduction (Calow \& Sibly 1990). The concept of the CEA approach is to quantify the available energy reserves $\left(E_{a}\right)$ and energy consumption $\left(E_{c}\right)$ at a cellular level of biological organization (biochemically) and to integrate them into a general stress indicator. Energy consumption is estimated by measuring the electron transport activity (ETS) at the mitochondrial level, whereas the energy reserve available for metabolism is assessed by measuring the total lipid, protein, and carbohydrate content of the test organism. The different energy reserve fractions were transformed into energetic equivalents using their respective energy of combustion, whereas the quantity of oxygen consumed, as derived from the ETS data, was transformed into energetic equivalents using the oxyenthalpic equivalents for an average lipid, protein, and carbohydrate mixture (Gnaiger 1983).

The CEA approach has proved to be ecologically relevant because cellular effects have been linked to higher levels of biological organization (De Coen \& Janssen 2003, Smolders et al. 2004). Although this technique was developed and validated initially with Daphnia magna, the CEA methodology can also be used with other invertebrates and vertebrates. So far, CEA has been applied in laboratory and field studies in different ecosystems (e.g., freshwater, estuarine, and marine ecosystems) using different organisms that cover a variety of animal taxa. A brief overview of these studies is given in Table 1.

*Corresponding author. E-mail: erk@irb.hr DOI: $10.2983 / 035.031 .0108$
From the practical side, the CEA methodology is very convenient when studying small invertebrates (e.g., amphipods, mysids, cladocerans), because a small amount of sample is needed to perform all the required biochemical analyses. On the other hand, when studying mussels (Mytilus sp.), the differences in biochemical composition of distinct animal tissues have to be taken into consideration. Because the CEA approach handles the biochemical parameters in terms of energy, different organs (e.g., mantle, digestive gland, gills, and muscles) contribute in a different extent to the energy budget of the total organism. Besides, biochemical composition of bivalves varies seasonally depending on the latitude at which they are found and is strongly related to water temperature, food availability, and the gametogenic cycle of the animal (Okumus \& Stirling 1998). A close relationship has also been reported between the gametogenic cycle, condition index, and the storage-consumption cycle of reserves, particularly glycogen (Gabbott 1975).

In this study we examined three mussel organs-gills, digestive gland, and mantle-which constitute the bulk of the soft tissue. The main goal of the current study was to determine which mussel tissue is the most suitable for the potential use of the CEA methodology as a biomarker in the indigenous mussel Mytilus galloprovincialis. In addition, we tested the applicability of the CEA methodology to the assessment of natural stress caused by strong fluctuations in salinity in the stratified estuary.

\section{MATERIALS AND METHODS}

\section{Sampling of Mussels}

Indigenous mussels (M. galloprovincialis) were collected from coastal rocks or concrete embankment structures between $0.5 \mathrm{~m}$ and $1 \mathrm{~m}$ below the sea surface. The sampling was performed in November 2008. Two sampling sites were selected in the Krka River estuary based on their differences in abiotic factors, primarily in terms of salinity. These sites were 


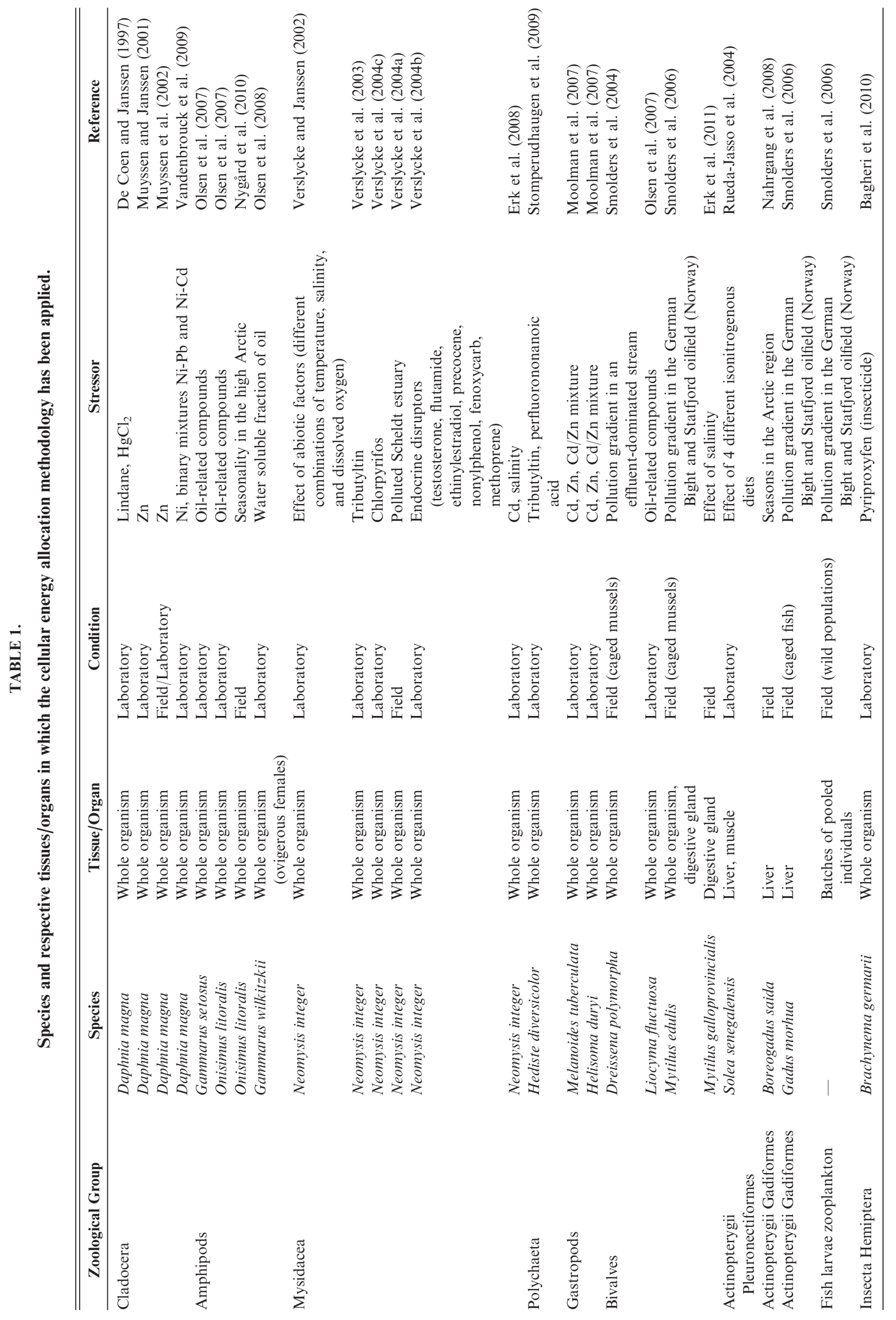


characterized as the coastal site (Zablace) with fewer salinity/ temperature $(\mathrm{S} / \mathrm{T})$ variations and the estuarine site (Martinska) with more $S / T$ variations (Erk et al. 2011). The estuary of the karstic river Krka is a salt-wedge, highly stratified estuary, located in the central part of the eastern Adriatic coast in Croatia (Fig. 1). This estuary is regarded as fairly unpolluted (Omanović et al. 2006, Cukrov et al. 2008).

Biometric measurements, sex determination, and dissection of digestive gland, mantle, and gills were performed immediately after collection at the marine station located at Martinska (Fig. 1). The tissues were stored in liquid nitrogen and transported to the laboratory in Zagreb for further analysis.

\section{Sex Determination}

The method used to determine sex of the mussels involved heating a piece of mantle tissue (20-50 mg wet weight) in a solution of trichloroacetic acid $(20 \% \mathrm{w} / \mathrm{v} ; 2 \mathrm{~mL})$ with a thiobarbituric acid $(0.75 \% \mathrm{w} / \mathrm{v} ; 0.5 \mathrm{~mL})$ (Jabbar \& Davies, 1987). The presence of a yellow or pink color, determined visually, was used to identify male and female animals, respectively.

\section{Cellular Energy Allocation Measurements}

Measurements of lipid, carbohydrate, and protein energy content, and ETS activity were performed in 10 individuals in each selected tissue and for each sampling site. At sampling site Zablace, 3 male and 7 female individuals were analyzed, whereas at site Martinska, 5 male and 5 female individuals were taken for

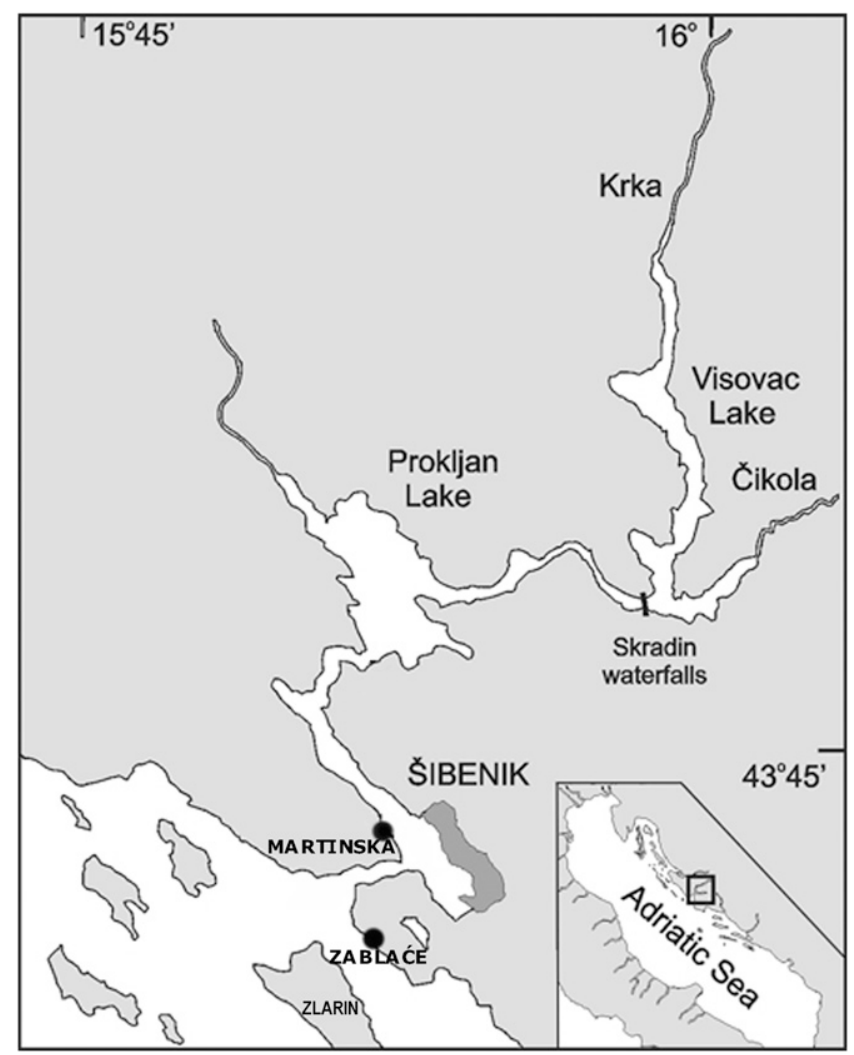

Figure 1. The Krka River estuary with indicated sampling sites (coastal site Zablaće and estuarine site Martinska). biochemical analyses. Each individual sample was measured in replicate.

CEA was measured according to Verslycke and Janssen (2002) with minor modifications. Lipids were extracted following the method of Bligh and Dyer (1959), and lipid concentrations were calculated by reference to standards of tripalmitin in chloroform. Protein content was measured by the method described by Bradford (1976) using bovine serum albumin as a standard. Carbohydrate content was analyzed with the phenolsulfuric acid method (Dubois et al. 1956), using glucose as a standard. The different energy reserve fractions (lipid, protein, carbohydrate = available energy, $\mathrm{E}_{\mathrm{a}}$ ) were transformed into energetic equivalents using their respective energy of combustion (39,500 mJ/mg lipid, 24,000 $\mathrm{mJ} / \mathrm{mg}$ protein, $17,500 \mathrm{~mJ} / \mathrm{mg}$ glycogen) (Gnaiger 1983). Energy consumption $\left(\mathrm{E}_{\mathrm{c}}\right)$ was estimated by measuring the activity of the mitochondrial ETS according to Owens and King (1975). The quantity of oxygen consumed, as derived from the ETS data, was transformed into energetic equivalents using the oxyenthalpic equivalents for an average lipid, protein, and carbohydrate mixture (484 $\left.\mathrm{kJ} / \mathrm{mol} \mathrm{O}_{2}\right)($ Gnaiger 1983).

The $E_{a}, E_{c}$ and CEA value were calculated as described by Verslycke and Janssen (2002):

$\mathrm{E}_{\mathrm{a}}$ (available energy $)=\mathrm{E}_{\text {carbohydrate }}+\mathrm{E}_{\text {lipid }}+\mathrm{E}_{\text {protein }}(\mathrm{mJ} / \mathrm{mg} \mathrm{ww})$

$\mathrm{E}_{\mathrm{c}}($ energy consumption $)=\mathrm{ETS}$ activity $(\mathrm{mJ} / \mathrm{mg} \mathrm{ww} / \mathrm{h})$

$\mathrm{CEA}($ cellular energy allocation $)=\mathrm{E}_{\mathrm{a}} / \mathrm{E}_{\mathrm{c}}$

From this, it is evident that a decrease of CEA indicates either a reduction in available energy or higher energy expenditure, both resulting in a lower amount of energy available for growth or reproduction.

\section{Statistical Analysis}

Statistical analyses were performed with the software packages SigmaStat for Windows version 3.5 (Systat Software, Inc., Chicago, IL) and Statistica 8.0 (StatSoft, Inc., Tulsa, OK). Differences in lipid, protein, carbohydrate energy contents, and differences in ETS activity between sampling sites were tested using the $t$-test. Differences between male and female in all measured parameters mentioned earlier were detected using the $t$-test. Differences between 3 organs in the parameters mentioned earlier were tested using 1-way ANOVA followed by pairwise multiple comparisons (Tukey test). All tests were performed at a probability level of 0.05 , or the probability levels are indicated in the figures. To assess the degree of association between variables and to gain insight into the separation of individuals between the sampling locations according to their energetic parameters, a correlation-based principal component analysis (PCA) was performed using a data matrix of 6 parameters ( $E_{\text {carbohydrates, }}$, $\mathrm{E}_{\text {proteins }}, \mathrm{E}_{\text {lipids }}, \mathrm{E}_{\mathrm{a}}, \mathrm{E}_{\mathrm{c}}$, and $\mathrm{CEA}$ ) and two sampling locations.

\section{RESULTS}

By transforming the measured concentrations of total carbohydrates, proteins, and lipids into their energetic equivalents, it was possible to compare the relative contribution of carbohydrate, lipid, and protein contents of digestive gland, mantle, and gills to the energy budget of the respective organ. The energy contents of total carbohydrates, proteins, and lipids measured in different organs are presented in Figure $2 \mathrm{~A}-\mathrm{C}$. 

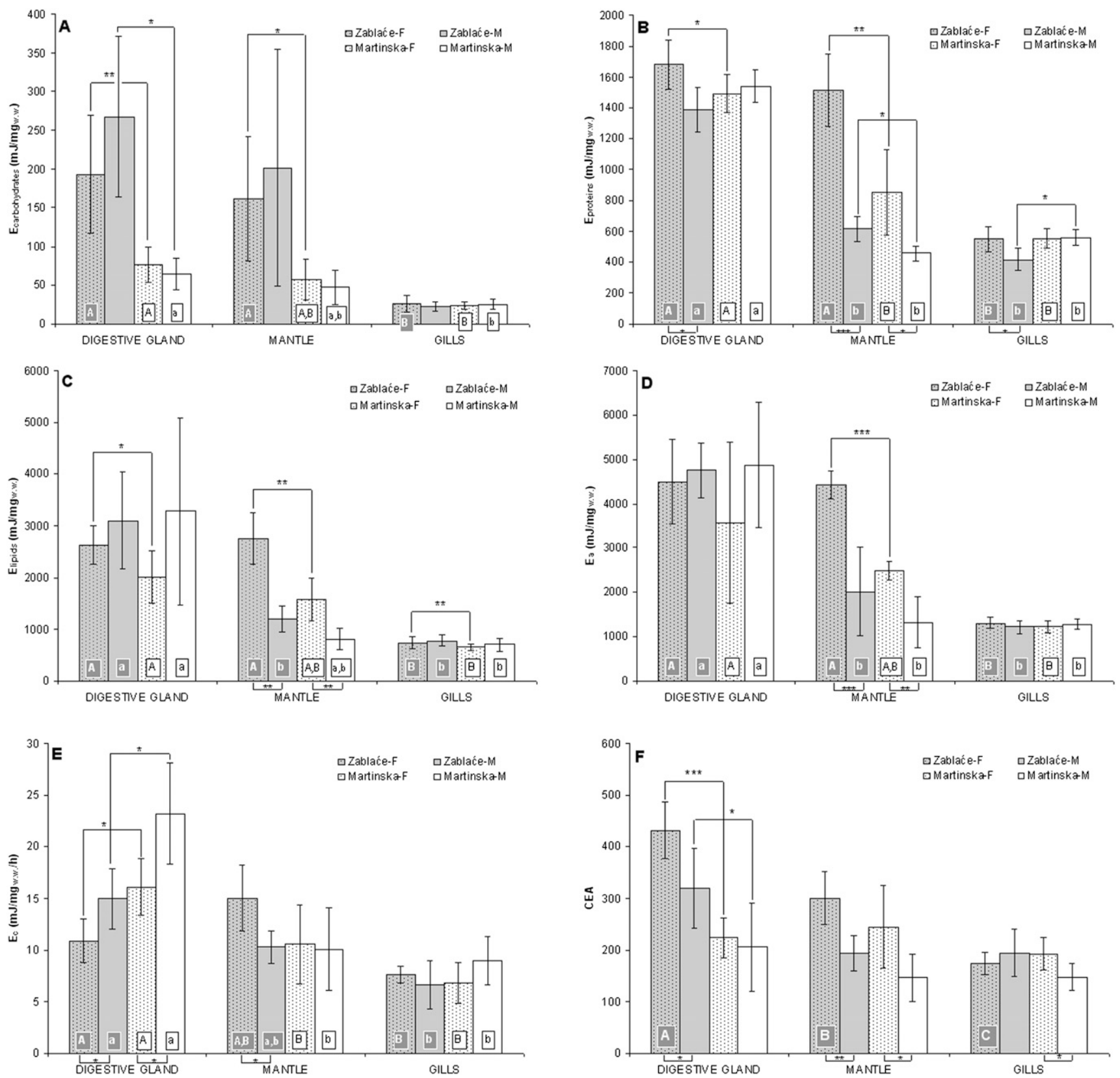

Figure 2. (A-F) The energy contents of total carbohydrates (A), total proteins (B) and total lipids (C), total available energy ( $E_{a}$; D), energy consumption $\left(\mathrm{E}_{\mathrm{c}} ; \mathrm{E}\right)$, and cellular energy allocation (CEA) values $(\mathrm{F})$ measured in digestive gland, mantle, and gills of mussels (Mytilus galloprovincialis) determined at 2 sampling sites in the Krka River estuary. Mean values and SDs are presented. Significant differences between male and female mussels and between the sampling sites are indicated with probability levels. ${ }^{*} \boldsymbol{P}<0.05,{ }^{* *} \boldsymbol{P}<0.01$, and $* * * \boldsymbol{P}<0.001$. Significant differences among digestive gland, mantle, and gills are indicated with different letters inside the respective bars, $P<0.05$ ). F, female; $M$, male, ww, wet weight.

The lowest values in energy content of all measured $\mathrm{E}_{\mathrm{a}}$ components - carbohydrates, proteins, and lipids - were evident in the gills (Fig. 2A-C; differences between the tissues are represented by different letters in the bars on the graph). These differences were significant in all cases between digestive gland and gills, but not always between mantle and gills (Fig. 2A-C).

In this study, the biochemical measurements were performed on both female and male mussels, and the respective results were analyzed independently. With regard to energy content of total carbohydrates, there were no significant differences be- tween male and female mussels in any of the analyzed tissues at both sampling sites (Fig. 2A). At the coastal site Zablace, females had greater energy content of total proteins in all 3 organs analyzed, whereas at the estuarine site the differences in the energy content of total proteins between male and female were not significant, except in the mantle (Fig. 2B; respective differences are marked bellow the bars on the graph). In digestive gland and gills, there were no significant differences in the energy content of total lipids between male and female; but in the mantle, females had greater energy content of total lipids at both sampling sites (Fig. 2C). Similar to the lipids, no significant 
differences in total $E_{a}$ between male and female were found in digestive gland and gills; but in the mantle, female had greater $\mathrm{E}_{\mathrm{a}}$ at both sampling sites (Fig. 2D). No significant differences were found in $\mathrm{E}_{\mathrm{c}}$ in the gills between male and female (Fig. 2E). However, in digestive gland males had greater $E_{c}$ than females at both sampling sites (Fig. 2E). In contrast, $\mathrm{E}_{\mathrm{c}}$ in mantle tissue was higher in female mussels from coastal site Zablace (Fig. 2E).

When considering the differences in all measured parameters between the 2 sampling sites, they were significant in most cases in digestive gland (Fig. 2A-C). Significant differences between the 2 sampling sites were found only in digestive gland-in particular, in $\mathrm{E}_{\mathrm{c}}$ (Fig. 2E) and in the calculated CEA values (Fig. 2F).

The PCA performed on the measured parameters in digestive gland showed that the first 2 axes accounted for $80.27 \%$ of variability between the mussels (Fig. 3A). The first axis explained $\sim 42 \%$ of total variance and displayed markedly positive loadings with the energy content of total carbohydrates ( $\left.E_{\text {carbohydrates }}\right)$, total $E_{a}$, and CEA values (Fig. 3A). The energy content lipids ( $\left.E_{\text {lipids }}\right)$ and proteins ( $\left.E_{\text {proteins }}\right)$ also showed a positive association with this axis, whereas an opposite relationship was observed for $\mathrm{E}_{\mathrm{c}}$ (Fig. 3A). This first axis separated individuals between the sampling sites (Fig. 3B) mainly according to the values of CEA and $E_{c}$, which were inversely related to each other (Fig. 3A). Thus, the right side of the first axis grouped the mussels from the coastal site Zablace (Fig. 3B) because they had high CEA values and a lower level of $E_{c}$. Most individuals from the estuarine site Martinska were grouped on the left side of the first axis (Fig. 3B) because these mussels had significantly higher $\mathrm{E}_{\mathrm{c}}$ and lower CEA values compared with those from the coastal site (Fig. 2E, F). The second axis had high loads with the energy content of lipids, total $\mathrm{E}_{\mathrm{a}}$, and $\mathrm{E}_{\mathrm{c}}$ (Fig. 3A). The observed variable association pattern is mainly related to 2 individuals at the site Martinska, which had a very high content of lipids and total $\mathrm{E}_{\mathrm{a}}$, but also high $\mathrm{E}_{\mathrm{c}}$. The PCA performed on the other 2 studied tissues (mantle and gills) did not show a clear separation of in- dividuals between the coastal and estuarine sampling sites according to their CEA and $\mathrm{E}_{\mathrm{c}}$ values (data not shown).

\section{DISCUSSION}

The stratified estuary represents a variable environment that affects significantly the metabolism of marine molluscs because of sometimes abrupt changes in salinity, which can cause important changes in the energy metabolism of animals. Organisms that live in such extreme environmental conditions might fail to reproduce, or may die as a result of natural environmental stress (e.g., thermal stress, salinity stress). Nevertheless, mussels (Mytilus sp.) are able to cope with changes in abiotic factors (salinity, temperature, dissolved oxygen) as a result of their ability to adapt to a wide range of salinities, and their efficient respiratory physiology (Zandee et al. 1986, Hawkins \& Bayne 1992). When organisms live in suboptimal environments, there is a cost of dealing with stress in terms of metabolic resources. The energy available for growth, based on energy budget analysis rather than on direct measurement of growth itself, therefore provides a sensitive measure of stress in an organism. To give reliable answers about the extent of changes in an organism's energy budget, the calculated CEA value should reflect the physiological status of the organism caused by external stress, not stress resulting from the normal reproductive cycle or gender differences. It has been shown that various aspects of the relationship exist between gametogenesis and the utilization of glycogen and protein reserves in the mantle tissue of $M$. edulis (Bayne et al. 1982). Furthermore, concerning the gender differences, Zaba and Davies (1980) found that during the spawning period, mantle tissue slices from female mussels metabolized glucose twice as rapidly as those from males per unit tissue weight. Livingstone (1981) demonstrated that the increase in glucose-6-phosphate dehydrogenase activity that occurred in the mantle tissue during the winter months was confined to female mussels. Therefore, it was important in the current study to identify the gender of mussels and take it into account to assess reliably the changes in CEA caused by natural stress.
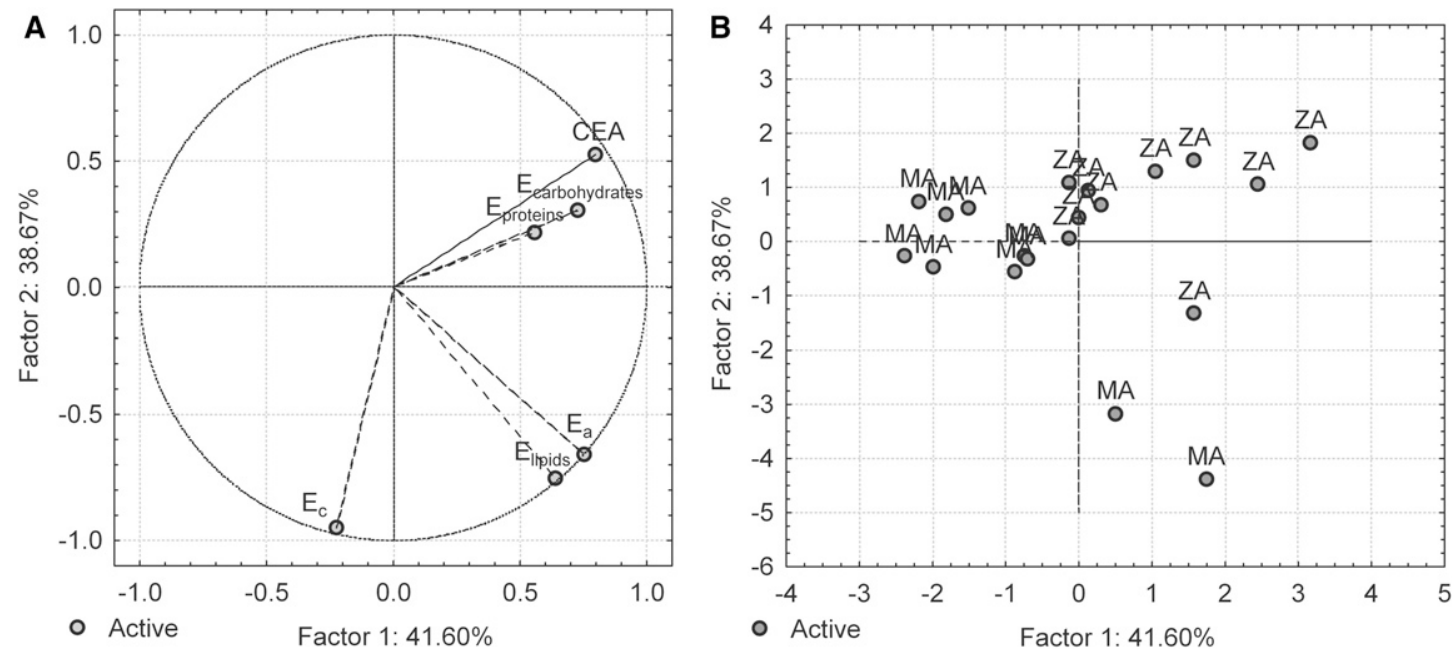

Figure 3. Principal component analysis applied to the energy content of total carbohydrates $\left(\mathrm{E}_{\text {carbohydrates }}\right)$, proteins $\left(\mathrm{E}_{\text {proteins }}\right)$, and lipids $\left(\mathrm{E}_{\text {lipids }}\right)$; total available energy $\left(E_{a}\right)$; energy consumption $\left(E_{c}\right)$; and cellular energy allocation (CEA) values measured in digestive gland of mussels $($ Mytilus galloprovincialis) sampled at 2 sites in the Krka River estuary. (A) Projection of the variables on the factor plane $(1 \times 2)$-descriptor scores. (B) Projection of the cases on the factor plane $(1 \times 2)$ —individual scores. MA, estuarine site Martinska; ZA, coastal site Zablaće. 
Our results show that measuring the CEA in different organs of mussels can give different information considering the same environmental conditions (Fig. 2F). The question was raised about the most appropriate target organ that could be applied for this purpose.

Bivalves of the genus Mytilus have a specific storage tissue, the mantle (containing two complementary types of cells), which undergoes seasonal variations in biochemical composition and in its cellular structure in relation to the reproductive cycle (Mathieu \& Lubet 1993). Because of the high weight contribution of mantle tissue when the gonads are developed within it, and its prominent variability in biochemical composition depending on the phase of the reproductive cycle, the changes in CEA caused by natural stress could be masked. In our study, the mantle tissue was under the strongest influence of the differences in protein and lipid content between male and female mussels (Fig. 2B, C), and therefore reflected, in the first place, physiological changes in the organism itself rather than those caused by environmental stress. The trends of total $E_{a}$ (Fig. 2D), which is a sum of energy content of carbohydrates, lipids, and proteins, actually reflected the trends of lipids (Fig. 2C), because lipid content gives the greatest contribution in energy equivalents $(39,500 \mathrm{~mJ} / \mathrm{mg})$. Because CEA is calculated as a ratio between $\mathrm{E}_{\mathrm{a}}$ and $\mathrm{E}_{\mathrm{c}}$, it strongly influences the final CEA value.

In mussels, gill filament consists mainly of a single layer of various types of epithelial cells (ciliated and nonciliated columnar cells, and mucous cells) and endothelial cells surrounding a central lumen and resting on a basement membrane (Dumouhtsidou \& Dimitriadis 2004) that are deprived in terms of lipid content. Scarce lipid content in gill tissue was also found in the current study (Fig. 2C), leading to the low $\mathrm{E}_{\mathrm{a}}$ values. In addition, the differences in $\mathrm{E}_{\mathrm{c}}$ between sampling sites were not detected in gills (Fig. 2E). As a consequence, the calculated CEA values in gills showed lower values than in mantle and digestive gland, with similar values at both sampling sites (Fig. 2F). Therefore, in this case, the changes in CEA caused by natural stress could not be detected.

With regard to the digestive gland, the breakdown of the digestive epithelium appears to be a generalized stress response, resulting not only from exposure to a wide range of contaminants, but also to physiological extremes such as increased salinity and starvation (Livingstone \& Pipe 1992). It is known that pollutant exposure may induce alterations in cell-type ratios in the digestive epithelium (basophilic cells become more abundant than digestive cells), and therefore the cellular composition of the digestive epithelium was examined as a marker of the general condition of the digestive gland (Cajaraville et al. 1990). Thus, the digestive gland appeared to be a good candidate for the target tissue for application of CEA as a physiological biomarker.

The correlation-based PCA was performed for each studied tissue to detect for which tissue all measured variables gave the distinction between the estuarine site and the coastal site. The clear separation of individuals between the sampling locations according to their energetic parameters by PCA (Fig. 3B) was obtained only for digestive gland. Indeed, in this study, CEA calculated from the measured biochemical parameters in digestive gland tissue demonstrated a clear difference between coastal and estuarine sampling sites (Fig. 2F), providing the measure of the natural stress posed by variations in salinity. Furthermore, the decisive energy component that contributes to the calculation of the CEA value was energy consumption $\left(E_{c}\right)$. Although significant differences in $E_{c}$ values were observed between male and female mussels, they were congruously higher in males from both sampling sites (Fig. 2E). This difference pointed to the importance of identifying mussel gender to assess reliably the changes in organism energy budget. $\mathrm{E}_{\mathrm{c}}$ was significantly greater in mussels living at the estuarine site Martinska than at the coastal site Zablace in both genders only when measurements were performed in digestive gland (Fig. $2 \mathrm{E}$ ). Mean $\mathrm{E}_{\mathrm{c}}$ was approximately $50 \%$ greater at the estuarine site than at the coastal site (Fig. 2E). Because Martinska was the site with high salinity fluctuations, mussels living at this site were exposed to a more demanding environment. To help reduce the rate of associated changes in cell volume, mussels respond immediately by closing the shell (Bayne et al. 1976). As osmoconformers, mussels maintain their internal salinity such that it is always equal to the surrounding seawater. They maintain the volume of cells relatively constant by actively regulating their internal concentration of free amino acids and ions to match the osmolarity of the environment (Lange 1972). All these regulatory processes are costly energetically. Thus, greater $\mathrm{E}_{\mathrm{c}}$ in mussels from the estuarine site than from the coastal site may be caused by the energetically costly maintenance of osmotic balance, and this distinction was detected only in digestive gland tissue.

In a field study with mussels caged along a pollution gradient in the Statfjord oilfield (Smolders et al. 2006), the use of digestive gland was shown to have the highest values of CEA at the reference station, but statistically significant differences were masked by the high SD. In the same study in the pollution gradient in the German Bight, the measurement of CEA was performed on whole mussel tissue, and the CEA value recorded at the reference station was similar to the CEA values at 2 stations along the pollution gradient. Thus, although we can only speculate, the possible reason for lack of ability to detect the differences in CEA values between the stations in the German Bight may lie in the choice of whole mussel tissue studied.

As a concluding remark, we note that using digestive gland tissue in CEA analysis as a physiological biomarker can have an advantage over using other mussel tissues or the whole soft tissue of mussels when detecting changes caused by environmental stress.

\section{ACKNOWLEDGMENTS}

The financial support by the Ministry of Science, Education and Sport of Republic Croatia (project no. 098-0982934-2721 and national monitoring project "Adriatic") is acknowledged.

\section{LITERATURE CITED}

Bagheri, F., K. Talebi \& V. Hosseininaveh. 2010. Cellular energy allocation of pistachio green stink bug, Brachynema germari Kol.
(Hemiptera: Pentatomidae) in relation to juvenoid pyriproxyfen. Afr. J. Biotechnol. 9:5746-5753. 
Bayne, B. L., A. Bubel, P. A. Gabbot, D. R. Livingstone, D. M. Lowe \& M. N. Moore. 1982. Glycogen utilisation and gametogenesis in Mytilus edulis L. Mar. Biol. Lett. 3:89-105.

Bayne, B. L., J. Widdows \& R. J. Thompson. 1976. Physiology II. In: B. L. Bayne, editor. Marine mussels: their ecology and physiology. Cambridge: Cambridge University Press. pp. 207-260.

Bligh, E. G. \& W. J. Dyer. 1959. A rapid method of total lipid extraction and purification. Can. J. Physiol. Pharmacol. 37:911-917.

Bradford, M. M. 1976. A rapid and sensitive method for the quantitation of microgram quantities of protein utilizing the principle of protein-dye binding. Anal. Biochem. 72:248-254.

Cajaraville, M. P., G. Diez, I. Marigomez \& E. Angulo. 1990. Responses of basophilic cells of the digestive gland of mussels to petroleum hydrocarbon exposure. Dis. Aquat. Organ. 9:221-228.

Calow, P. \& R. M. Sibly. 1990. A physiological basis of population processes: ecotoxicological implications. Funct. Ecol. 4:283-288.

Cukrov, N., P. Cmuk, M. Mlakar \& D. Omanović. 2008. Spatial distribution of trace metals in the Krka River, Croatia: an example of the self-purification. Chemosphere 72:1559-1566.

De Coen, W. M. \& C. R. Janssen. 1997. The use of biomarkers in Daphnia magna toxicity testing: IV. Cellular energy allocation: a new methodology to assess the energy budget of toxicant-stressed Daphnia populations. J. Aquat. Ecosyst. Stress Recovery 6:43-55.

De Coen, W. M. \& C. R. Janssen. 2003. The missing biomarker link: relationships between effects on the cellular energy allocation (CEA) biomarker of toxicant-stressed Daphnia magna and corresponding population characteristics. Environ. Toxicol. Chem. 22: 1632-1641.

Dubois, M., K. A. Gilles, J. K. Hamilton, P. A. Rebers \& F. Smith. 1956. Colorimetric method for determination of sugars and related substances. Anal. Chem. 28:350-356.

Dumouhtsidou, G. P. \& V. K. Dimitriadis. 2004. Lysosomal, tissue and cellular alterations in the gills, palps and intestine of the mussel Mytilus galloprovincialis, in relation to pollution. Mar. Biol. 145:109-120.

Erk, M., D. Ivanković \& Ž. Strižak. 2011. Cellular energy allocation in mussels (Mytilus galloprovincialis) from the stratified estuary as a physiological biomarker. Mar. Pollut. Bull. 62:1124-1129.

Erk, M., B. T. A. Muyssen, A. Ghekiere \& C. R. Janssen. 2008. Metallothionein and cellular energy allocation in the estuarine mysid shrimp Neomysis integer exposed to cadmium at different salinities. J. Exp. Mar. Biol. Ecol. 357:172-180.

Gabbott, P. A. 1975. Storage cycles in marine bivalve molluscs: a hypothesis concerning the relationship between metabolism and gametogenesis. In: H. Barnes, editor. Proceedings of the $9^{\text {th }}$ European Marine Biology Symposium. Aberdeen: University Press. pp. 191-211.

Gnaiger, E. 1983. Calculation of energetic and biochemical equivalents of respiratory oxygen consumption. In: E. Gnaiger \& H. Forstner, editors. Polarographic oxygen sensors: aquatic and physiological applications. Berlin: Springer Verlag. pp. 337-345.

Hawkins, A. J. S. \& B. L. Bayne. 1992. Physiological interrelations, and the regulation of production. In: E. Gosling, editor. The mussel Mytilus: ecology, physiology, genetics and culture. Amsterdam: Elsevier. pp. 171-222.

Jabbar, A. \& J. I. Davies. 1987. A simple and convenient biochemical method for sex identification in the marine mussel, Mytilus edulis L. J. Exp. Mar. Biol. Ecol. 107:39-44.

Lange, R. 1972. Some recent work on osmotic, ionic and volume regulation in marine animals. Oceanogr. Mar. Biol. Annu. Rev. 10:97-136.

Livingstone, D. R. 1981. Induction of enzymes as a mechanism for the control of metabolism in marine invertebrates: glucose-6-phosphate dehydrogenase from mantle and hepatopancreas of the common mussel, Mytilus edulis L. Comp. Biochem. Physiol. 69B:147-156.

Livingstone, D. R. \& R. K. Pipe. 1992. Mussels and environmental contaminants: molecular and cellular aspects. In: E. Gosling, editor.
The mussel Mytilus: ecology, physiology, genetics and culture. Amsterdam: Elsevier. pp. 425-464.

Mathieu, M. \& P. Lubet. 1993. Storage tissue metabolism and reproduction in marine bivalves: a brief review. Invertebr. Reprod. Dev. 23:123-129.

Moolman, L., J. H. J. Van Vuren \& V. Wepener. 2007. Comparative studies on the uptake and effects of cadmium and zinc on the cellular energy allocation of two freshwater gastropods. Ecotoxicol. Environ. Saf. 68:443-450.

Muyssen, B. T. A. \& C. R. Janssen. 2001. Multigeneration zinc acclimation and tolerance in Daphnia magna: implications for water-quality guidelines and ecological risk assessment. Environ. Toxicol. Chem. 20:2053-2060.

Muyssen, B. T. A., C. R. Janssen \& B. T. A. Bossuyt. 2002. Tolerance and acclimation to zinc of field-collected Daphnia magna populations. Aquat. Toxicol. 56:69-79.

Nahrgang, J., J. S. Christiansen, H. Hop, E. Sva \& L. Camus. 2008. Seasonal variability of PAH biomarkers in the polar cod (Boreogadus saida) with applications for oil toxicity testing. Mar. Environ. Res. 66:178-179.

Nygård, H., J. Wallenschus, L. Camus, O. Varpe \& J. Berge. 2010. Annual routines and life history of the amphipod Onisimus litoralis: seasonal growth, body composition and energy budget. Mar. Ecol. Prog. Ser. 417:115-126.

Okumus, I. \& H. P. Stirling. 1998. Seasonal variations in the meat weight, condition index and biochemical composition of mussels (Mytilus edulis L.) in suspended culture in two Scottish sea lochs. Aquaculture 159:249-261.

Olsen, G. H., J. Carroll, E. Sva \& L. Camus. 2008. Cellular energy allocation in the Arctic sea ice amphipod Gammarus wilkitzkii exposed to the water soluble fractions of oil. Mar. Environ. Res. 66:213-214.

Olsen, G. H., E. Sva, J. Carroll, L. Camus, W. De Coen, R. Smolders, H. Øveraas \& K. Hylland. 2007. Alterations in the energy budget of Arctic benthic species exposed to oil-related compounds. Aquat. Toxicol. 83:85-92.

Omanović, D., Ž. Kwokal, A. Goodwin, A. Lawrence, C. Banks, R. Compton \& Š. Komorsky-Lovrić. 2006. Trace metal detection in Šibenik Bay, Croatia: cadmium, lead and copper with anodic stripping voltammetry and manganese via sonoelectrochemistry: a case study. J. Iran. Chem. Soc. 3:128-139.

Owens, T. G. \& F. D. King. 1975. The measurement of respiratory electron transport activity in marine zooplankton. Mar. Biol. 30: 27-36.

Rueda-Jasso, R., L. E. C. Conceição, J. Dias, W. De Coen, E. Gomes, J. F. Rees, F. Soares, M. T. Dinis \& P. Sorgeloos. 2004. Effect of dietary non-protein energy levels on condition and oxidative status of Senegalese sole (Solea senegalensis) juveniles. Aquaculture 231:417-433.

Smolders, R., L. Brevoets, W. De Coen \& R. Blust. 2004. Cellular energy allocation in zebra mussels exposed along a pollution gradient: linking cellular effects to higher levels of biological organization. Environ. Pollut. 129:99-112.

Smolders, R., K. Cooreman, P. Roose, R. Blust \& W. De Coen. 2006. Cellular energy allocation in caged and pelagic free-living organisms along two North Sea pollution gradients. In: K. Hylland, T. Lang \& A. D. Vethaak, editors. Biological effects of contaminants in marine pelagic ecosystems. Brussels: SETAC Press. pp. $235-252$.

Stomperudhaugen, E. S., N. H. Hanssen Øverås, K. Langford, W. De Coen, R. Smolders \& K. Hylland. 2009. Cellular energy allocation in Hediste diversicolor exposed to sediment contaminants. J. Toxicol. Environ. Health A 72:244-253.

Vandenbrouck, T., A. Soetaert, K. van der Ven, R. Blust \& W. De Coen. 2009. Nickel and binary metal mixture responses in Daphnia magna: molecular fingerprints and (sub)organismal effects. Aquat. Toxicol. 92:18-29. 
Verslycke, T., A. Ghekiere \& C. R. Janssen. 2004a. Seasonal and spatial patterns in cellular energy allocation in the estuarine mysid Neomysis integer (Crustacea: Mysidacea) of the Scheldt estuary (The Netherlands). J. Exp. Mar. Biol. Ecol. 306:245-267.

Verslycke, T. \& C. R. Janssen. 2002. Effects of a changing abiotic environment on the energy metabolism in the estuarine mysid shrimp Neomysis integer (Crustacea: Mysidacea). J. Exp. Mar. Biol. Ecol. 279:61-72.

Verslycke, T., S. Poelmans, K. De Wasch, H. F. De Brabander \& C. R. Janssen. 2004b. Testosterone and energy metabolism in the estuarine mysid Neomysis integer (Crustacea: Mysidacea) following exposure to endocrine disruptors. Environ. Toxicol. Chem. 23:1289-1296.

Verslycke, T., S. D. Roast, J. Widdows, M. B. Jones \& C. R. Janssen. 2004c. Cellular energy allocation and scope for growth in the estuarine mysid Neomysis integer (Crustacea: Mysidacea) following chlorpyrifos exposure: a method comparison. J. Exp. Mar. Biol. Ecol. 306:1-16.

Verslycke, T., J. Vercauteren, C. Devos, L. Moens, P. Sandra \& C. R. Janssen. 2003. Cellular energy allocation in the estuarine mysid shrimp Neomysis integer (Crustacea: Mysidacea) following tributyltin exposure. J. Exp. Mar. Biol. Ecol. 288:167-179.

Widdows, J. \& D. Johnson. 1988. Physiological energetics of Mytilus edulis: scope for growth. Mar. Ecol. Prog. Ser. 46:113-121.

Zaba, B. N. \& J. I. Davies. 1980. Glucose metabolism in an in vitro preparation of the mantle tissue of Mytilus edulis. Mar. Biol. Lett. 1:235-243.

Zandee, D. I., D. A. Holwerda, J. H. Kluytmans \& A. De Zwaan. 1986. Metabolic adaptations to environmental anoxia in the intertidal bivalve mollusc Mytilus edulis. Neth. J. Zool. 36:322-343. 